\title{
ANALISIS KEJADIAN DIARE BERDASAR KEADAAN SARANA SANITASI DASAR RUMAH DAN PERILAKU PENGHUNI DI DESA GISIK CEMANDI SIDOARJO TAHUN 2016
}

\author{
Firdha Rizkhy Asedha, Siti Surasri, Sudjarwo
}

\begin{abstract}
ABSTRAK
Diare merupakan penyakit endemis di Indonesia dan merupakan penyakit potensial KLB yang sering disertai dengan kematian. Penelitian yang dilakukan di desa Gisik Cemandi ini bertujuan untuk menganalisis faktor Diare yang mungkin menjadi penyebab, yaitu Sarana Sanitasi Dasar dan perilaku penghuni.

Survey Cross Sectional dilakukan terhadap 84 sampel yang dipilih secara random dari 511 populasi. Data dikumpulkan dengan cara mengobservasi objek dan wawancara terhadap ibu Balita. Analisis Chi2 dilakukan untuk menguji hipotesis.

Hasil penelitian menunjukkan sebagian besar rumah memiliki sarana sanitasi dasar yang tidak memenuhi syarat walaupun sebagian besar perilaku penghuni rumah masuk dalam kategori baik. Terbukti ada hubungan antara keadaan sarana sanitasi dasar rumah dengan kejadian diare. Ada hubungan antara perilaku penghuni rumah dengan kejadian diare. Ada hubungan antara keadaan sarana sanitasi dasar dan perilaku penghuni rumah dengan kejadian diare. Karena ketiganya memiliki nilai $p$ kurang dari a $(0,05)$.

Kesimpulan dari penelitian ini bahwa keadaan sarana sanitasi dasar dan perilaku penghuni rumah berhubungan dengan kejadian diare. Karena itu disarankan agar lebih meningkatkan keadaan sarana sanitasi dasar, mempertahankan keadaan sarana sanitasi dasar yang telah memenuhi syarat, juga mempertahankan perilaku baik penghuni rumah supaya dapat mengurangi angka kejadian diare.
\end{abstract}

Kata kunci: diare, faktor perilaku, sanitasi dasar rumah

\section{PENDAHULUAN}

Sanitasi berhubungan dengan kesehatan lingkungan yang mempengaruhi derajat kesehatan masyarakat. Buruknya kondisi sanitasi akan berdampak negatif di banyak aspek kehidupan, mulai dari turunnya kualitas lingkungan hidup masyarakat, tercemarnya sumber air minum bagi masyarakat, meningkatnya jumlah kejadian diare dan munculnya beberapa penyakit. Faktor yang berperan penting dalam menentukan derajat kesehatan adalah perilaku, karena ketiga faktor lain seperti lingkungan, kualitas pelayanan kesehatan maupun genetika kesemuanya masih dapat dipengaruhi oleh perilaku. Diare merupakan penyakit endemis di Indonesia dan merupakan penyebab kematian nomor empat pada semua golongan umur dalam kelompok penyakit menular.

tinja merupakan sumber beberapa penyakit tertentu terutama penyakit yang menular melalui saluran alat cerna, tinja mencemari tanah dan air yang menyebabkan air sebagai vehicle menunjukkan perannya dalam proses penularan penyakit apabila air tanah yang menjadi sumber air minum terkontaminasi oleh tinja atau bakteri tinja patogen (Didik Sarudji, 2006). Pembuangan Air Limbah: lebih kurang $80 \%$ dari air yang digunakan bagi kegiatan manusia sehari-hari tersebut dibuang lagi dalam bentuk yang sudah kotor (tercemar). Air buangan yang bersumber dari rumah tangga (domestic wastes water), yaitu air limbah yang berasal dari pemukiman penduduk. Pada umumnya air limbah ini terdiri dari ekskreta (tinja dan air seni), air bekas cucian dapur dan kamar mandi, dan umumnya terdiri dari bahan-bahan organik (Soekidjo Notoatmodjo, 1997).

Pengetahuan manusia diperoleh melalui mata dan telinga. Pengetahuan atau kognitif merupakan domain yang sangat penting dalam membentuk tindakan seseorang (Soekidjo Notoatmodjo, 2003). Sikap belum merupakan suatu tindakan atau aktivitas, akan tetapi merupakan predisposisi tindakan suatu perilaku. Sikap itu masih merupakan reaksi tertutup, bukan merupakan reaksi terbuka atau tingkah laku yang terbuka. Sikap merupakan kesiapan untuk bereaksi terhadap objek di lingkungan tertentu sebagai suatu penghayatan terhadap objek (Soekidjo Notoatmodjo, 2003). Suatu sikap belum otomatis terwujud dalam suatu tindakan (overt behavior). Untuk terwujudnya sikap menjadi suatu perbuatan nyata diperlukan faktor pendukung atau suatu kondisi yang memungkinkan, anatara lain adalah fasilitas (Soekidjo Notoatmodjo, 2003). Menurut Depkes RI Direktorat Jenderal Pengendalian Penyakit dan Penyehatan Lingkungan (2011), Diare adalah suatu kondisi dimana seseorang buang air besar dengan konsistensi lembek atau cair, bahkan dapat berupa air saja dan frekuensinya lebih sering (biasanya tiga kali atau lebih) dalam satu hari. Penyebab diare dapat dikelompokkan menjadi: 1) Virus, Rotavirus, Adenovirus, 2) Bakteri. Eschericia coli, Shigella sp., Vibrio Cholerae, 3) Parasit, Entamoeba histolytica, Giardia lamblia, Cryptosporidium.

Penularan Diare 
1) Melalui air yang merupakan media penularan utama. Diare dapat terjadi bila seseorang menggunakan air minum yang sudah tercemar. Baik tercemar dari sumbernya, tercemar selama perjalanan sampai ke rumahrumah, atau tercemar pada saat disimpan di rumah. Pencemaran di rumah terjadi bila tempat penyimpanan tidak tertutup atau apabila tangan yang tercemar menyentuh air pada saat mengambil air dari tempat penyimpanan.

2) Melalui tinja terinfeksi. Tinja yang sudah terinfeksi mengandung virus atau bakteri dalam jumlah besar. Bila tinja tersebut dihinggapi oleh binatang dan kemudian binatang tersebut hinggap di makanan, maka makanan itu dapat menularkan diare ke orang yang memakannya.

Pencegahan Diare:

a. Menggunakan air bersih. Tanda-tanda air bersih adalah ' 3 Tidak', yaitu tidak berwarna, tidak berbau, dan tidak berasa.

b. Memasak air sampai mendidih sebelum diminum untuk mematikan sebagian besar kuman penyakit.

c. Mencuci tangan dengan sabun pada waktu sebelum makan, sesudah makan, dan sesudah buang air besar (BAB).

d. Menggunakan jamban yang sehat.

\section{RUMUSAN MASALAH}

Apakah ada hubungan keadaan sarana sanitasi dasar dan perilaku penghuni rumah dengan kejadian diare di Desa Gisik Cemandi Kecamatan Sedati Kabupaten Sidoarjo Tahun 2016

Tujuan Penelitian: Menganalisis hubungan keadaan sarana sanitasi dasar dan perilaku penghuni rumah dengan kejadian diare di Desa Gisik Cemandi Kecamatan Sedati Kabupaten Sidoarjo Tahun 2016.

\section{METODE PENELITIAN}

Jenis penelitian ini menggunakan metode penelitian analitik, yakni survei atau penelitian yang mencoba menggali bagaimana dan mengapa fenomena kesehatan itu terjadi. Dan pendekatan atau jenis survei yang digunakan adalah survey Cross Sectional, yaitu suatu penelitian untuk mempelajari

Tabel 1.

Hubungan Keadaan Sarana Sanitasi Dasar dan Perilaku Penghuni Rumah Dengan Kejadian Diare di Desa Gisik Cemandi Kecamatan Sedati Kabupaten Sidoarjo Tahun 2016

\begin{tabular}{|c|c|c|c|c|c|c|c|c|}
\hline \multirow[t]{3}{*}{ No } & \multirow{3}{*}{$\begin{array}{c}\text { Perilaku } \\
\text { Penghuni } \\
\text { Rumah }\end{array}$} & \multirow[t]{3}{*}{ Sarana Sanitasi Dasar } & \multicolumn{4}{|c|}{ Kejadian Diare } & \multicolumn{2}{|c|}{ Jumlah } \\
\hline & & & \multicolumn{2}{|c|}{ Sakit } & \multicolumn{2}{|c|}{ Tidak Sakit } & & \\
\hline & & & $\mathrm{N}$ & $\%$ & $\mathrm{~N}$ & $\%$ & $\mathrm{~N}$ & $\%$ \\
\hline \multirow{4}{*}{$\begin{array}{l}1 . \\
2 .\end{array}$} & Cukup & Tdk Memenuhi Syarat & 21 & $75 \%$ & 7 & $25 \%$ & 28 & $100 \%$ \\
\hline & Baik & Tdk Memenuhi Syarat & 8 & $14,3 \%$ & 36 & $64,3 \%$ & 44 & $78,6 \%$ \\
\hline & & Memenuhi Syarat & 0 & $0 \%$ & 12 & $21,4 \%$ & 12 & $21,4 \%$ \\
\hline & & mlah & 29 & $34,5 \%$ & 55 & $64,5 \%$ & 84 & $100 \%$ \\
\hline
\end{tabular}

dinamika korelasi atau hubungan keadaan sarana sanitasi dasar dan perilaku penghuni rumah dengan kejadian diare, melalui cara pendekatan, observasi atau pengumpulan data sekaligus pada suatu saat. Sebagai populasi pada penelitian ini adalah seluruh rumah dan penghuni rumah di Desa Gisik Cemandi, Kecamatan Sedati, Kabupaten Sidoarjo. Sedangkan sampel penelitian ini adalah 84 rumah tangga dari 511 rumah tangga yang dipilih dengan teknik pengambilan Simple Random Sampling atau Sampel secara Acak Sederhana. Dan analisis data yang digunakan yaitu analisa statistik menggunakan program SPSS metode Uji Chi Square dengan tingkat kemaknaan $5 \%$.

\section{HASIL PENELITIAN DAN PEMBAHASAN}

Kejadian Diare: Pengamatan terhadap 84 sampel rumah tangga menghasilkan kasus diare yang menimpa 55 rumah tangga. Jadi hanya 29 yang mengaku tidak mengalami diare selama kurun waktu penelitian.

Keadaan sarana sanitasi dasar: Dari 84 sampel, hanya 12 yang keadaan Sarana sanitasi dasar nya memenuhi syarat. Jadi ada 72 sampel yang tidak memenuhi syarat.

Keadaan perilaku penghuni rumah relatif baik, karena tidak ada yang berperilaku kurang, hanya 28 rumah tangga yang berperilaku cukup, sedang sisanya ( 58 rumah tangga) berperilaku baik.

Kalau dihubungkan antara perilaku penghuni rumah, keadaan sarana sanitasi dasar, dan kejadian diare, maka akan tergambar keadaan sebagai berikut: pada rumah tangga dengan keadaan sarana sanitasi dasar memenuhi syarat dan penghuni rumah yang berperilaku baik tidak ada kejadian diare, sedangkan pada rumah tangga dengan keadaan sarana sanitasi dasar tidak memenuhi syarat dan penghuni rumah yang berperilaku cukup terdapat kejadian diare sebesar 75\% (21 rumah). Uji statistik dengan metode Chi Square diperoleh nilai $\mathrm{p}=0,004$ dan jika digunakan a 0,05 , maka kesimpulannya $\mathrm{H}_{0}$ ditolak, yang berarti ada hubungan antara keadaan sarana sanitasi dasar dan perilaku penghuni rumah dengan kejadian diare di Desa Gisik Cemandi Kecamatan Sedati Kabupaten Sidoarjo. Periksa tabel di bawah ini. 
Dari laporan yang ada pada tabel 1) diketahui bahwa keadaan sarana sanitasi dasar memenuhi syarat dengan perilaku penghuni rumah baik tidak ada yang disertai kejadian diare, sedangkan sanitasi dasar dan perilaku penghuni rumah dengan kejadian diare.

Dalam hal ini yang menyebabkan ada hubungan antara keadaan sarana sanitasi dasar dan perilaku penghuni rumah dengan kejadian diare karena sebagian besar rumah yang perilaku penghuninya termasuk dalam kategori cukup memiliki sarana sanitasi dasar tidak memenuhi syarat dan ada anggota keluarga yang menderita penyakit diare. Hal tersebut terjadi karena keadaan sarana sanitasi dasar di rumah dipengaruhi oleh perilaku penghuni rumahnya sendiri dan kedua hal tersebut merupakan faktor penting dalam menentukan derajat kesehatan masyarakat, buruknya keadaan sanitasi dasar dan perilaku akan berdampak negatif di banyak aspek kehidupan, mulai dari turunnya kualitas lingkungan hidup masyarakat, meningkatnya jumlah kejadian diare, dan munculnya beberapa penyakit lainnya.

Maka dari itu bagi keluarga yang keadaan sarana sanitasi dasar terutama sarana penyediaan air bersihnya memenuhi syarat hendaknya dipertahankan atau ditingkatkan lagi sehingga dapat menjadi contoh atau motivator bagi keluarga yang mempunyai keadaan sarana penyediaan air bersih yang belum memenuhi syarat, didukung dengan meningkatkan kebiasaan cuci tangan pakai sabun dan air mengalir sebelum maupun setelah melakukan aktivitas apapun. Diharapkan juga kepada pihak Puskesmas untuk memberi pembinaan kepada kader desa dalam bidang kesehatan lingkungan terutama sarana sanitasi dasar. Karena melalui kader - kader ini mungkin nantinya dapat lebih menggerakkan perubahan perilaku masyarakat.

\section{SIMPULAN DAN SARAN \\ SIMPULAN}

Berdasarkan hasil penelitian, analisis, dan pembahasan yang telah dilakukan, maka dapat diambil kesimpulan Ada hubungan antara keadaan sarana sanitasi dasar dan perilaku penghuni rumah dengan kejadian diare di Desa Gisik Cemandi, Kecamatan Sedati, Kabupaten Sidoarjo.

\section{DAFTAR PUSTAKA}

Dedi Alamsyah, Ratna Muliawati. 2013. Pilar Dasar IImu Kesehatan Masyarakat. Yogyakarta, Nuha Medika.

Departemen Kesehatan RI Direktorat Jenderal Pengendalian Penyakit dan Penyehatan Lingkungan. 2011. Buku Saku Petugas Kesehatan Lintas Diare. Departemen Kesehatan RI. keadaan sarana sanitasi dasar tidak memenuhi syarat dengan penghuni rumah hanya berperilaku cukup terdapat kejadian diare sebesar 75\% (21 rumah). Dan ada hubungan antara keadaan sarana

\section{SARAN}

Bagi Puskesmas

- Puskesmas sebagai instansi terkait dapat menjadikan hal tersebut sebagai bahan evaluasi untuk dapat memperbaiki keadaan sarana sanitasi dasar seperti sarana pembuangan kotoran manusia dan sarana pembuangan air limbah dengan melakukan pemicuan atau penyuluhan.

- Diharapkan juga kepada pihak Puskesmas untuk memberi pembinaan kepada kader desa dalam bidang kesehatan lingkungan terutama sarana sanitasi dasar. Karena melalui kader - kader ini mungkin nantinya dapat lebih menggerakkan perubahan perilaku masyarakat.

Bagi Masyarakat

- Bagi keluarga yang keadaan sarana penyediaan air bersihnya memenuhi syarat hendaknya dipertahankan atau ditingkatkan lagi sehingga dapat menjadi contoh atau motivator bagi keluarga yang mempunyai keadaan sarana penyediaan air bersih yang belum memenuhi syarat, didukung dengan meningkatkan kebiasaan cuci tangan pakai sabun dan air mengalir sebelum maupun setelah melakukan aktivitas apapun.

- Sebaiknya masyarakat menggunakan bentuk pembuangan sampah dengan cara diangkut petugas kebersihan dua hari sekali, dan menggunakan tempat sampah memenuhi syarat yakni kapasitas cukup menampung sampah yang dihasilkan sesuai dengan frekuensi pengambilannya, tertutup rapat, mudah dikosongkan mudah dibersihkan, dan tidak mudah dirusak binatang pengganggu.

- Bagi penghuni rumah yang sudah memiliki perilaku baik terhadap kejadian diare hendaknya dapat menjadi contoh, motivator, atau sumber informasi dengan cara memanfaatkan pertemuan antar warga sebagai wadah pembinaan bagi penghuni rumah yang masih berperilaku cukup ataupun kurang baik.

Dinas Kesehatan Provinsi Jawa Timur. 2013. Profil Kesehatan Provinsi Jawa Timur Tahun 2012. Surabaya, Dinas Kesehatan Provinsi Jawa Timur.

Entjang, Indan. 2000. IImu Kesehatan Masyarakat. Bandung, PT. Citra Aditya Bakti.

Fahmi, Umar. 2012. Dasar-Dasar Penyakit Berbasis Lingkungan. Jakarta, Raja Grafindo Persada. 
Harry. 2011. Penilaian Rumah Sehat. http://id.scribd.com/mobile/doc/14005325 1/Penilaian-rumah-sehat. 08 Januari 2016.

Kementerian Kesehatan Republik Indonesia. 2014. Profil Kesehatan Indonesia Tahun 2013. Jakarta, Kementerian Kesehatan Republik Indonesia.

Krisnawati, Irma. 2009. Hubungan Sarana Sanitasi Dasar Rumah Dengan Kejadian Diare di Kelurahan Simolawang Kota Surabaya Tahun 2009.

Milka, Silvia. 2008. Hubungan Keadaan Sarana Sanitasi Dasar Dengan Kejadian Diare Tahun 2008 (Di Desa Jogosatru Kecamatan Sukodono Kabupaten Sidoarjo).

Notoatmodjo, Soekidjo. 2003. Pendidikan dan Perilaku Kesehatan. Jakarta, PT. Rineka Cipta.

Notoatmodjo, Soekidjo. 2007. Kesehatan Masyarakat. Jakarta, PT. Rineka Cipta.

Notoatmodjo, Soekidjo. 2012. Metodologi Penelitian Kesehatan. Jakarta, PT. Rineka Cipta.

Pemerintah Desa Gisik Cemandi. 2011. Profil Desa Gisik Cemandi Tahun 2011. Sidoarjo, Pemerintahan Desa Gisik Cemandi.

Peraturan Menteri Kesehatan Republik Indonesia No. 416/MenKes/Per/IX/1990 Tentang
Syarat - syarat dan Pengawasan Kualitas Air.

Putu, Ni Luh. 2006. Hubungan Kualitas Sarana Sanitasi Dasar Dengan Penyakit Diare di Pemukiman Nelayan Kelurahan Bulak Banteng Kecamatan Kenjeran Surabaya Tahun 2006.

Ratu, Andreas. 2007. Hubungan Kondisi Sarana Sanitasi Dasar Perumahan dan Perilaku Pendudukan dengan Kejadian Diare (Studi di Kelurahan Ekasapta Kecamatan Larantuka Kabupaten Flores Timur Tahun 2006).

Sarudji, Didik. 2006. Kesehatan Lingkungan. Sidoarjo, Media Ilmu.

Sugiyono. 2014. Metode Penelitian Kuantitatif, Kualitatif, dan R\&D. Bandung, Alfabeta.

Widoyono. 2011. Penyakit Tropis: Epidemiologi, Penularan, Pencegahan, \& Pemberantasannya. Edisi Kedua. Jakarta, Erlangga.

Wijayanti, Fajar, 2005. Hubungan Tingkat Pendidikan, Pengetahuan Kepala Keluarga Penghuni Rumah Susun Dengan Pemeliharaan Sarana Sanitasi Dasar di Rumah Susun Penjaringan Timur Surabaya Tahun 2005. 